\title{
APPLICATION OF REAL-TIME LOCATING IN HEALTH CARE
}

\author{
Dubravko ŽIGMAN, Slaven KRAJINA, and Marija KRZNARIĆ \\ Polytechnic of Zagreb, Zagreb, Croatia \\ Received in May 2009 \\ Accepted in November 2009
}

\begin{abstract}
This paper describes real-time locating technology and its possible use in health care. Real time locating may be applied in different segments of everyday life, including hospitals (medical equipment and devices, locating patients, and alarm in case of emergency), working environment (locating persons to control access to restricted areas or in case of fire to see if anyone has been trapped inside the building), sports, logistics, retail trade, and offices. Tagged hospital equipment is easy to trace inside hospital premises and the system makes it possible to track patients and staff, and to redistribute work in particular wards.
\end{abstract}

KEY WORDS: determining location, global positioning system, intelligent systems, mobile identifier, radiofrequency identification technology, wireless network

Positioning or locating is a term which may be rather confusing for most people in everyday life. The easiest way to explain the difference between the two terms is to answer the following questions: "Where am I?" and "Where is XY?" The answer to the first question gives information about the location where we are at the moment, which is what the global position system (GPS) does. The answer to the second question gives information about the location of a person or an object in relation to a reference point. According to the ISO/IEC FDIS 19762-5, a real-time locating system (RTLS) is a "...combination of hardware and software that is used to continuously determine and provide the real time position of assets and resources equipped with devices designed to operate with the system" (1).

A few other standards covering RLTS have been issued (i.e. ISO/IEC 24730-1:2006, ISO/IEC 247302:2006, and ISO/IEC 24730-5 WD), but new editions and revisions are still expected.

Information about a person's or an object's location is never the result of one step only or of one operation only. In order to determine location, RTLS needs to receive feedback without time delay, which is the greatest challenge for current software solutions and built-in locating algorithms. Locating cannot rely on information about the distance or about the angle alone, or on a combination of the two. For normal functioning, RTLS has to consist of a mobile identifier (tag), access point providing reference information about the location which sends and receives the signal, and of software using algorithms to calculate the location of the a tag attached to a person or an object (2). At least three access points in the system are required to obtain good signal quality and therefore accurate information about tag location. However, there are factors which make locating more complex than that. The most important is signal coverage. It is therefore necessary to measure it before the system is implemented (Figure 1). The task of the location server is to keep a database with coordinates of reference access points and media access control (MAC) addresses, which identify each tag and to process, collect, and distribute this information (Figure 2) (3). Information about tag location may be obtained on user's request or these data can be processed constantly, and any location change can be stored in the database. This would depend on technical 


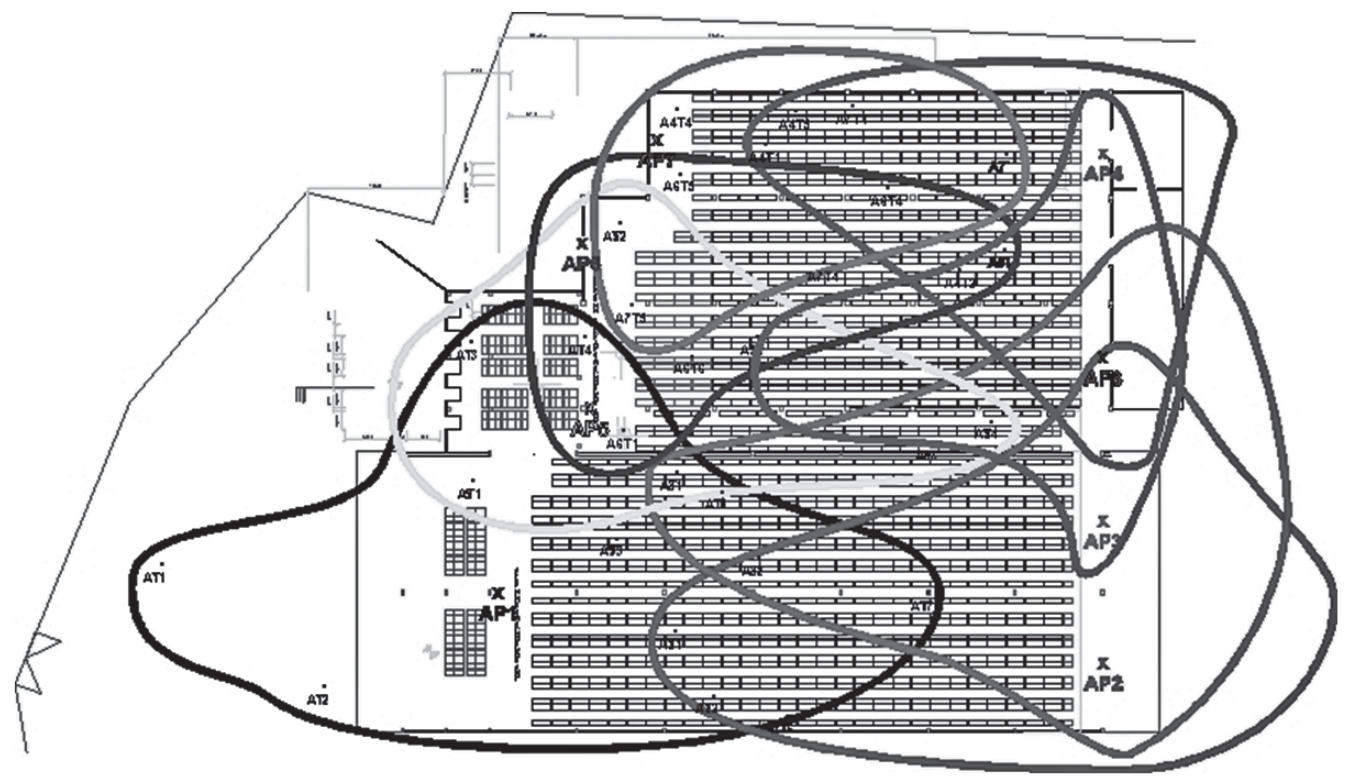

Figure 1 Measure of signal coverage

characteristics of the tags, their built-in battery life in particular. To retrieve information on request, the tag is activated via radio signal, and software gets necessary information to calculate its exact location. In constant tracking mode, tags send information all the time, which of course shortens battery life.

\section{RTLS types}

In view of algorithms applied to determine tag location $(4,5)$, real-time locating systems may be divided in four basic types based on cell of origin, lateration, angulation, and pattern recognition.

The concept of cell of origin (or "nearest access point" in Wi-Fi 802.11 systems) is one of the simplest ways to estimate location in any system based on radio "cells". In its simplest form, this technique does not resolve the position of the mobile device, but indicates the tag. Lateration systems measure the arrival time of a signal transmitted from a mobile device to several receiving sensors. Because signals

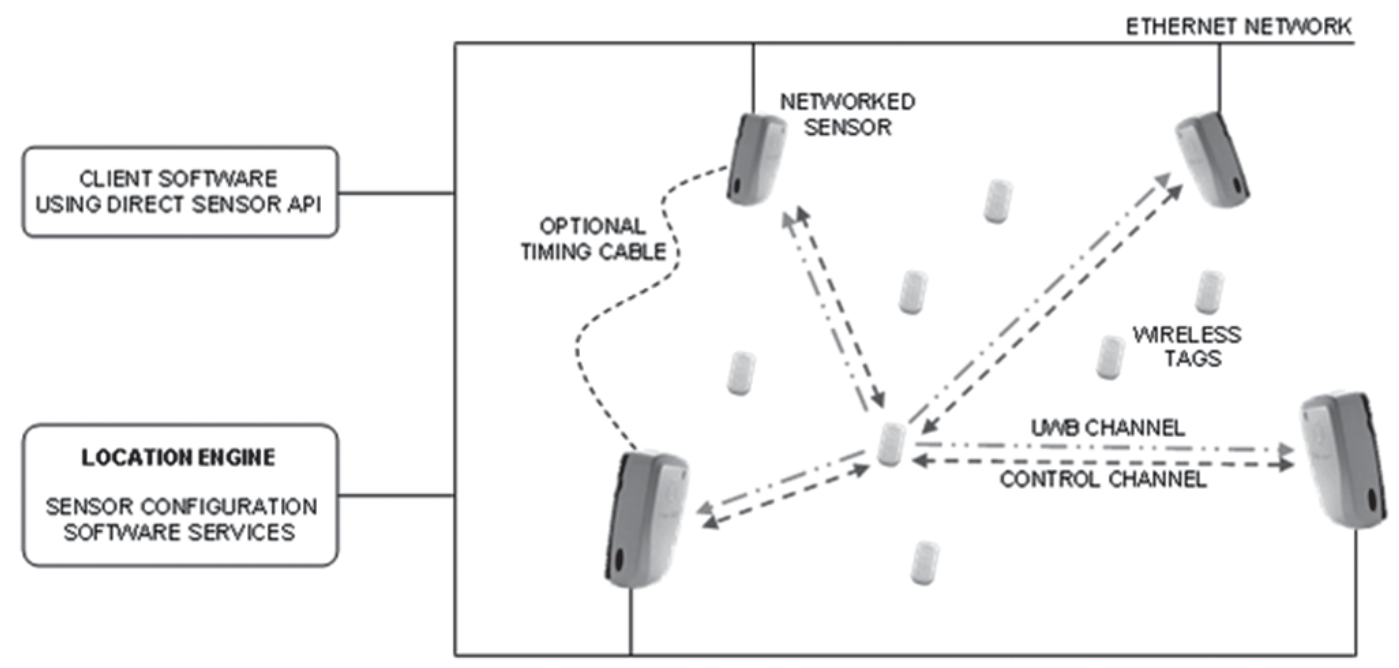

Figure 2 Tasks in RTLS (3) 

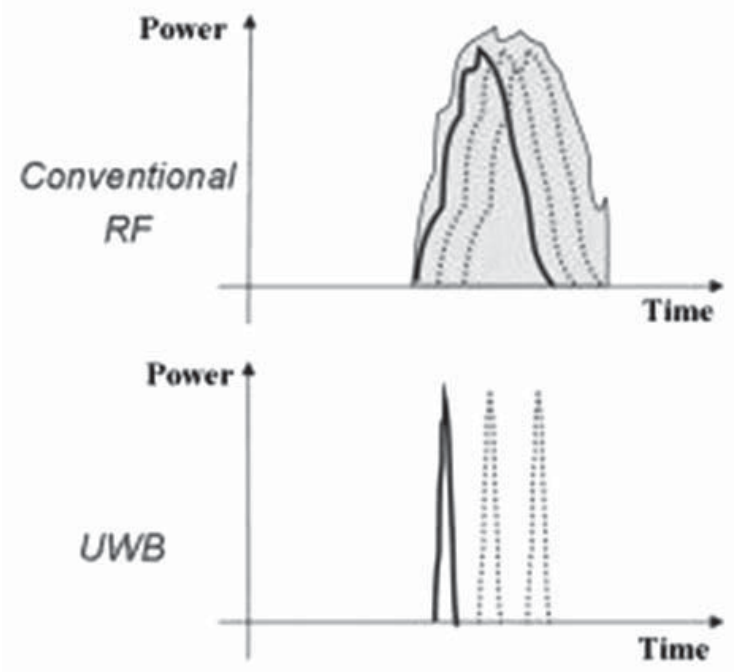

UWB's short duration pulses are easier to filter in order to determine which signals are correct and which are generated from multipath.

Figure 3 Difference between $R F$ and UWB signals (6)

travel approximately at the speed of light $(\sim 3 \mathrm{x}$ $\left.10^{8} \mathrm{~m} \mathrm{~s}^{-1}\right)$, the distance between the mobile device and the sensor can be determined from the time the signal travelled between them. Angulation system locates the mobile device by determining the angle at which signals arrive to the receiving sensor.

Location patterning system is based on the sampling and recording radio signal behaviour patterns in specific environments. It does not require specialised hardware in either the mobile device or the receiving sensor. However, proprietary tags and software on client device make it possible for the "client side" to report signal strength to the server). While designing the system, it is possible to implement one or more algorithms to optimise performance for two or more environments such as outdoor and indoor.

\section{Choice of RTLS technology}

The choice of technology for a locating system depends on the environment in which the system will be implemented, on required locating accuracy, and on its purpose. The technologies to choose from include standard 802.11 wireless local area networks, (WLAN) (5); ultra wideband networks (UWB) (3) as shown in Figure 3 (6); ultrasound technology; frequency-modulated continuous-wave (FMCW) radar systems (7); radiofrequency identification (RFID) (8); and optical infrared (IR) technology.

\section{APPLICATION OF REAL-TIME LOCATING IN HEALTH CARE}

Since the introduction of centralised WLAN in 2003 (9), it has been possible to locate devices and people in such environments as health care (Figure 4) (5). Today, WLAN real-time locating systems make use of existing network infrastructures if there are any.

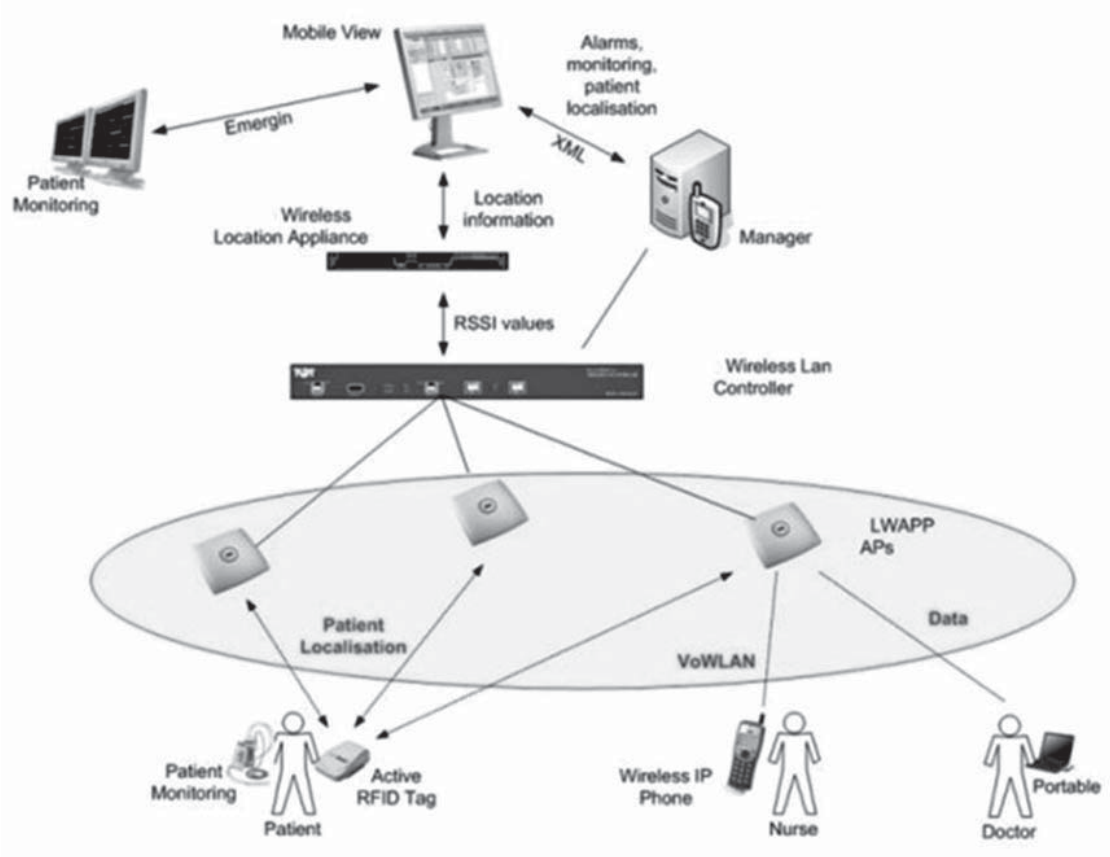

Figure 4 Application of RTLS in health care (5) 
With optimum radio signal coverage, locating error is $5 \mathrm{~m}$ to $10 \mathrm{~m}(10)$, which makes it possible to locate medical equipment (Figure 5) (11), hospital beds, wheelchairs, hospital staff, and patients within hospital premises. This accuracy however can be achieved only where there is a dense distribution of Wi-Fi access points with redundant coverage. Otherwise, locating error with WiFi-based RTLS can be as high as $50 \mathrm{~m}$. Tagged instruments are quicker and easier to track, which leaves hospital staff more time to take care of patients. Tagging can also address theft by setting off alarm if tags leave system perimeter. Tagged staff can be located in real time in case of emergency. It is also possible to track patients to see how occupied particular wards are and how to redistribute work in them.

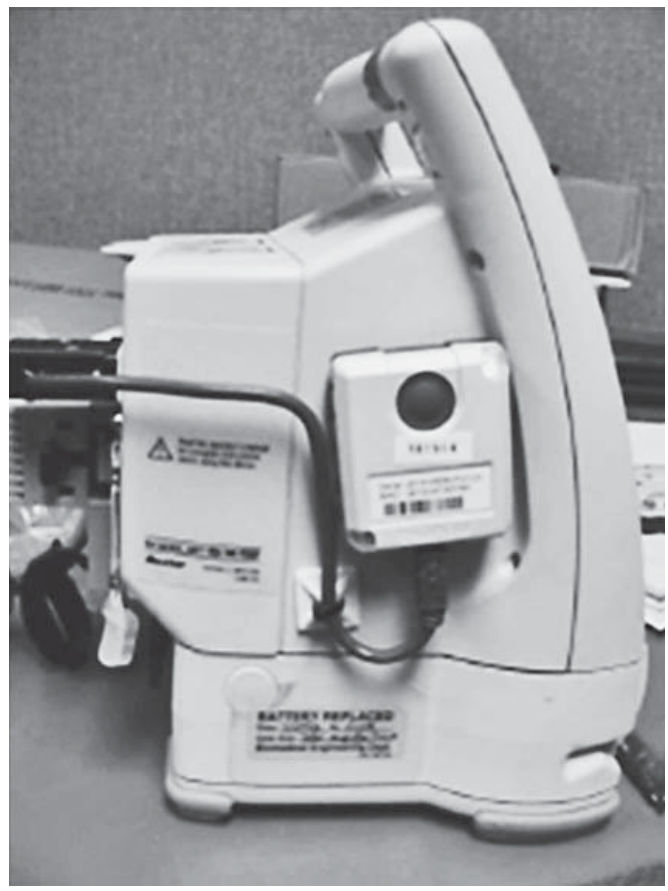

Figure 5 Tag attached to an infusion pump (11)

New expert systems have been proposed in literature, which might increase RTLS application in health care (12-14). These systems could combine several RTLS technologies to reduce locating error to $1 \mathrm{~cm}$, but this is very difficult and expensive to achieve. Such accuracy is needed only for specialised diagnostical medical applications. It can be achieved only with visual systems (cameras, lasers) and not with RF-based RTLS. In this way several tags could be attached to patient's arms or legs (Figure 6) (10) to track movement and even distinguish usual from unusual movement. These systems could find application in retirement homes and hospitals and could alarm staff automatically if the tagged person falls. Or if the tag movement is too slow or does not exist at all, this might point to a stroke. An epileptic episode could be registered as erratic movement of the tag.

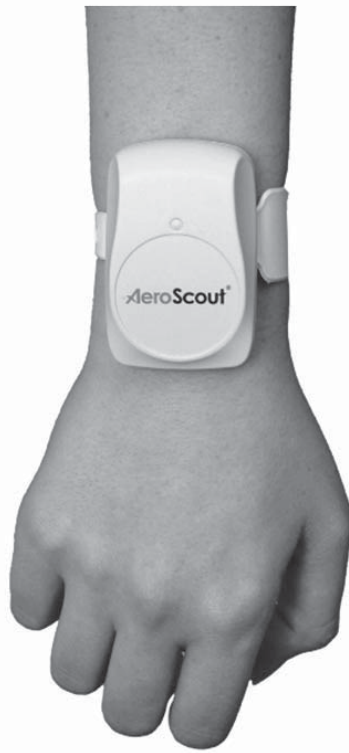

Figure 6 Tag attached to arm (10)

In conclusion, recent findings suggest that realtime locating technologies could help to optimise some working procedures in health care settings, and to improve patient care, which in turn might reduce operational costs. Such technologies are continuously developed, but their effective implementation requires understanding, experience, and continuous education of healthcare personnel.

\section{REFERENCES}

1. International Organization for Standardization (ISO). ISO/IEC 19762-5 Information technology - Automatic identification and data capture (AIDC) techniques Harmonized vocabulary - Part 5: Locating systems. Geneva: ISO; 2007.

2. Ultra-wideband. [displayed 17 February 2009]. Available at http://reference.findtarget.com/search/Ultra-wideband.

3. Ubisense limited. LocationEngineConfig User Manual [CDROM]. Cambridge (UK); 2007.

4. Real time locating. [displayed 6 December 2008]. Available at http://www.nationmaster.com/encyclopedia/Real-timelocating.

5. Cisco. Wi-Fi Location-Based Services-Design and Deployment Considerations [displayed 6 July 2009]. Available at http://cisco.hosted.jivesoftware.com/docs/DOC- 
3418;jsessionid=47996EEC12D19F8D3EDFB97AFB5281D 4.htm.

6. Becker B. Application range of UWB-technologie. In: Sharma A. SMART Solutions 2008. Isernhagen: rfid ready Verlag; 2008. p. 1-144.

7. Moussally GJ. 3D imaging radar system [CD-ROM]. USA; 1997.

8. Coca E, Popa V. Evaluation of RFID location system. In Editura Universitatii Suceava, editors. Proceedings of the $5^{\text {th }}$ Seminar of Distributed Systems; 12-14 Sept 2007. Suceava, Romania. 2007. p. 123-9.

9. Info-Tech Research Group. Is a Wireless LAN Real Time Location System for You? [displayed 6. December 2008.]. Available for member at page http://www.infotech.com/ research/is-a-wireless-lan-real-time-location-system-foryou.

10. AeroScout Inc. Case Studies Healthcare [CD-ROM]. Redwood City (CA, USA); 2007.
11. Ikonen J. Ekahau Inc. PowerPoint presentation [displayed 6. December 2008]. Available at http://www. finproevents. fi/tiedostot/default/finpro1000000209.pdf

12. Delbaere K, Crombez G, Vanderstraeten G, Willems T, Cambier D. Fear-related avoidance of activities, falls and physical frailty. A prospective community-based cohort study. Age Ageing 2004;33:368-73.

13. Pérolle G, Fraisse P, Mavros M, Etxeberria I. Automatic fall detection and activity monitoring for elderly. In: Jordanova M, Lievens F, editors. E-Health Proceedings of Med-e-Tel 2006 The International Trade Event and Conference for eHealth, Telemedicine and Health ICT. Luxembourg: G. D. of Luxembourg; 2006. p. 2-5.

14. Pollack ME. Intelligent assistive technology: the present and the future. In: Carbonell JG, Siekmann J, editors. User Modelling 2007, Lecture Notes in Computer Sciences. Berlin/Heidelberg: Springer; 2007. p. 5-6. 


\section{Sažetak}

\section{PRIMJENA LOCIRANJA U REALNOM VREMENU U ZDRAVSTVENOJ NJEZI}

U ovom radu nastojao se opisati sustav lociranja u realnom vremenu. Dani su osnovni pojmovi, specifikacije, kao i mogućnosti primjene u zdravstvenoj njezi. Lociranje u realnom vremenu nalazi primjenu u mnogim segmentima društvenog života kao što su bolnice (lociranje medicinskih naprava i pomagala unutar bolnice, lociranje bolesnika i alarmiranje u slučaju nužde), radno okruženje čovjeka (lociranje osoba u svrhu kontrole pristupa, tj. pristupa štićenom prostoru ili u slučaju požara čime se može utvrditi lokacija ljudi u zgradi te je li netko ostao zarobljen u zgradi), sport, logistika, maloprodaja, uredi. Označavanjem bolničkih osnovnih sredstava za rad omogućeno je njihovo praćenje i brže lociranje unutar bolničkih ustanova, također omogućuje se nadzor nad pacijentima, lociranje po odjelima i praćenje zauzetosti pojedinog odjela te preraspodjela rada pojedinog odjela.

KLJUČNE RIJEČI: bežične mreže, inteligentni sustavi, lociranje pacijenata, mobilni identifikator, određivanje lokacije, radio-frekvencijska identifikacijska tehnologija, sustav globalnog pozicioniranja

CORRESPONDING AUTHOR:

Dubravko Žigman, M.Sc.

Polytechnic of Zagreb

Vrbik 8, 10000 Zagreb, Croatia

E-mail:dzigman@tvz.hr 